\title{
Pengukuran Kualitas Layanan Publik Studi di Kantor Desa Tunjungtirto Kecamatan Singosari Kabupaten Malang
}

\author{
Ida Bagus Suardika ${ }^{*}$, Nelly Budiharti², AdyUtomo ${ }^{3}$ \\ 1. Teknik Industri, ITN-Malang \\ 2. Teknik Industri, ITN-Malang \\ 3. Teknik Sipil, ITN-Malang \\ E-mail : Idabagus-suardika57@gmail.com
}

\begin{abstract}
Abstrak
Masyarakat desa Tunjungtirto kecamatan Singosari Kabupaten Malang, dalam melaksanakan aktivitas kehidupan kesehariannya tidak terlepas dari layanan public yang diselenggarakan oleh kantor desa.

Penelitian ini melaporkan hasil evaluasi atas kualitas layanan kantor desa selaku penyelenggara pemerintahan, bila dievaluasi oleh warga desa selaku konsumen dari kantor desa tersebut.

Data penelitian ini diperoleh dari penyebaran kuesioner yang diisi oleh Warga desa Tujungtirto Kabupaten Malang. Kuesioner di bagikan kepada 85 responden yaitu warga desa yang sedang maupun telah melaksanakan pengurusan administrasi di kantor desa tersebut.

Dari Pengujian validitas \& reliabilitas Instrumen Servqual yang digunakan untuk mengevaluasi kualitas layanan kantor desa tunjungtirto, diperoleh hasil dari ke dua puluh dua (22) item Parasuraman tereduksi menjadi tujuh belas (17) item yang tepat digunakan sebagai pengukur kualitas layanan pemerintah desa (layanan Publik).

Hasil Servqual gap menunjukan bahwa secara umum persepsi warga lebih tinggi dibandingkan ekspektasinya. Hal tersebut bermakna bahwa warga menerima layanan pada skor berkualitas.
\end{abstract}

Kata Kunci : Kantor desa, Validitas dan reliabilitas, Servqual Gap.

\section{Pendahuluan}

Konteks penyelenggaraan pelayanan public oleh pemerintah merupakan factor utama dalam upaya pemenuhan hak masyarakat. Masyarakat selalu membutuhkan pelayanan yang berkualitas dari pemerintah. Bila mengacu pada Kepmenpan No.63/KEP/M.PAN/7/2003 tentang pedoman pelayanan publik, isinya menjelaskan bahwa standar dalam pelayanan public meliputi : prosedur pelayanan, waktu pelaksanaan, biaya pelayanan, produk layanan, sarana - prasarana dan kompetensi petugas dalam memberikan pelayanan. Pedoman tersebut memberikan kebebasan kepada pemerintah daerah kabupaten maupun kota untuk mengupayakan terciptanya pelayanan masyarakat dengan mengacu pada standar pelayanan dan asas-asas pelayanan yang berkualitas. 
Masyarakat desa Tunjungtirto kecamatan Singosari Kabupaten Malang, dalam melaksanakan aktivitas kehidupan kesehariannya tidak terlepas dari layanan public yang diselenggarakan oleh kantor desa. Kantor desa menyediakan petugas untuk berinteraksi dengan warga secara langsung serta melaksanakan kegiatan yang berkaitan dengan kebutuhan administrative warga desa.

Penelitian ini melaporkan hasil evaluasi atas kualitas layanan kantor desa selaku penyelenggara pemerintahan, bila dievaluasi oleh warga desa selaku konsumen dari kantor desa tersebut. Berdasarkan uraian latar belakang tersebut, maka dirumuskan permasalahan sebagai berikut:

1. Bagaimana Reliabilitas dan Validitas Instrumen ServiceQuality, bila digunakan untuk mengukur kualitas layanan publik.

2. Bagaimana skor kualitas pelayanan (servqual gap) yang diberikan oleh pemerintah desa tersebut diterima oleh masyarakat desa Tunjungtirto (perceived service quality).

Tujuan dari penelitian ini adalah :

1. Mengevaluasi Instrument ServiceQuality yang digunakan sebagai alat ukur kualitas layanan.

2. Menganalisa kualitas layanan kantor desa Tunjungtirto Kabupaten Malang dari sudut pandang masyarakat desa sebagai konsumen kantor desa.

\section{Metodologi Penelitian}

Data penelitian ini diperoleh dari penyebaran kuesioner yang diisi oleh Warga desa Tujungtirto Kabupaten Malang. Kuesioner di bagikan kepada 85 responden yaitu warga desa yang sedang maupun telah melaksanakan pengurusan administrasi di kantor desa tersebut. Instrumen SERVQUAL menyediakan dasar untuk mengukur kualitas. Dilakukan penyesuaian atas pernyataan yang ada di dalam instrument tersebut, untuk dapat digunakan sebagai alat ukur kualitas layanan public di kantor desa. Ke lima dimensi utama kualitas Tangible, Reliability, Responsivenes, Assurance, dan Empathy (Parasuraman et al. 1985, 1988). tetap digunakan.

Ide sentral dalam model SERVQUAL ini adalah bahwa kualitas jasa layanan merupakan fungsi dari perbedaan skor antara persepsi dan harapan $(\mathrm{P}-\mathrm{E})$. Masing - masing kelompok atribut layanan itu dikelompokkan kedalam lima dimensi sebagai berikut :

1. Reliability, Ability to perform the promised service dependably and accurately.

2. Responsiveness, Willingness to help customer and provide prompt service.

3. Assurance, Knowledge and courtesy of employees and their ability to convey trust and confidence.

4. Empathy, Caring, individualized attention the firm provides its customer.

5. Tangibles, Appearance of physical facilities, equipment, personnel, and communication materials. (Parasuraman, 2004:45)

Skor kualitas layanan diperoleh jika kinerja layanan yang diterima konsumen (persepsi) sama atau melebihi dari layanan yang diharapkan (ekspektasi) konsumen. Secara rinci terdapat tiga jenjang keluaran (outcome) tentang kualitas yaitu dari jenjang terbawah kualitas tidak dapat diterima, berkualitas yaitu bertemunya persepsi dengan harapan, terakhir kualitas unggul yaitu yang diterima melebihi dari harapan akan layanan tersebut

Digunakan skala five-point Likert. Skala likert tersebut terdiri dari (1)“ sangat tidak setuju”, (2)“tidak setuju”,(3) "ragu”,(4) “ setuju”, dan (5) "sangat setuju”. Skala yang tersedia tersebut 
Jurnal Teknologi dan Manajemen Industri, Vol. 4 No. 1, Februari 2018

Pascasarjana Institut Teknologi Nasional Malang

diharapkan mampu memberikan pilihan yang spesifik bagi responden atas pernyataan yang ada di dalam instrumen penelitian.

\section{Hasil Penelitian}

\section{Uji Reliabilitas Instrumen}

Sebelum instrumen penelitian digunakan untuk mengevaluasi layanan kantor desa, terlebih dahulu dilakukan uji reliabilitas dan validitas instrumen. Disebarkan pada sejumlah responden, dalam hal ini adalah masyarakat warga desa yang telah ataupun sedang menggunakan jasa layanan di kantor tersebut. Sejumlah 20 responden dipilih secara acak (random) dan diminta untuk mengisi 22 item pernyataan yang ada sebagai bagian dari pre-test instrumen.

Tujuannya adalah untuk mendapatkan derajat stabilitas, konsistensi, akurasi atas instrument penelitian yang digunakan. (Groth-Marnat 2008).

Dari uji yang dilakukan diperoleh hasil cronbach's alpha pada kisaran nilai 0.7790. Hasil tersebut lebih besar bila dibandingkan dengan nilai $\mathrm{r}$ tabel $=0.361$. $(0.7790>0.361)$. Dengan demikian dapat dinyatakan bahwa instrument reliable untuk dianalis lebih lanjut. Terdapat lima (5) item nilai alpha if item deleted yang tinggi. Yaitu pada variable P1, P10, P12, P19 dan P22. Tingginya nilai alpha if item deleted tersebut menunjukkan rendahnya korelasi diantara variable instrumen. Oleh karenanya diputuskan untuk mengeleminir kelima variable tersebut.

Tabel 1 Hasil Perhitungan Cronbach $f$ s Alpha

\begin{tabular}{|c|l|c|c|c|c|c|l|}
\hline No & Variable & $\begin{array}{c}\text { Scale } \\
\text { Mean if } \\
\text { Item } \\
\text { Deleted }\end{array}$ & $\begin{array}{c}\text { Scale } \\
\text { Variance } \\
\text { if Item } \\
\text { Deleted }\end{array}$ & $\begin{array}{c}\text { Corrected } \\
\text { Item-Total } \\
\text { Correlation }\end{array}$ & $\begin{array}{c}\text { Cronbach's } \\
\text { Alpha if } \\
\text { Item } \\
\text { Deleted }\end{array}$ & $\begin{array}{c}\text { Cronbach's } \\
\text { Alpha }\end{array}$ & \multicolumn{1}{|c|}{ Keputusan } \\
\hline 1 & P2 & 65,26316 & 19,4269 & 0,352492 & 0,834196 & 0,835 & $\begin{array}{l}\text { Lolos Uji Validitas } \\
\text { \& Reliabilitas }\end{array}$ \\
\hline 2 & P3 & 65,57895 & 18,70175 & 0,530352 & 0,820846 & 0,835 & $\begin{array}{l}\text { Lolos Uji Validitas } \\
\text { \& Reliabilitas }\end{array}$ \\
\hline 3 & P4 & 65,42105 & 18,47953 & 0,615306 & 0,81519 & 0,835 & $\begin{array}{l}\text { Lolos Uji Validitas } \\
\text { \& Reliabilitas }\end{array}$ \\
\hline 4 & P5 & 65,78947 & 20,95322 & 0,070104 & 0,839466 & 0,835 & $\begin{array}{l}\text { Lolos Uji Validitas } \\
\text { \& Reliabilitas }\end{array}$ \\
\hline 5 & P6 & 65,47368 & 19,7076 & 0,530942 & 0,821998 & 0,835 & $\begin{array}{l}\text { Lolos Uji Validitas } \\
\text { \& Reliabilitas }\end{array}$ \\
\hline 6 & P7 & 65,21053 & 19,39766 & 0,639808 & 0,817124 & 0,835 & $\begin{array}{l}\text { Lolos Uji Validitas } \\
\text { \& Reliabilitas }\end{array}$ \\
\hline 7 & P8 & 65,31579 & 20,11696 & 0,396512 & 0,828527 & 0,835 & $\begin{array}{l}\text { Lolos Uji Validitas } \\
\text { \& Reliabilitas }\end{array}$ \\
\hline 8 & P9 & 65,31579 & 20,00585 & 0,422381 & 0,827205 & 0,835 & $\begin{array}{l}\text { Lolos Uji Validitas } \\
\text { \& Reliabilitas }\end{array}$ \\
\hline
\end{tabular}


Jurnal Teknologi dan Manajemen Industri, Vol. 4 No. 1, Februari 2018

Pascasarjana Institut Teknologi Nasional Malang

\begin{tabular}{|c|l|c|c|c|c|c|l|}
\hline 9 & P11 & 65,26316 & 19,31579 & 0,722714 & 0,814452 & 0,835 & $\begin{array}{l}\text { Lolos Uji Validitas } \\
\text { \& Reliabilitas }\end{array}$ \\
\hline 10 & P14 & 65,52632 & 19,04094 & 0,619899 & 0,81638 & 0,835 & $\begin{array}{l}\text { Lolos Uji Validitas } \\
\text { \& Reliabilitas }\end{array}$ \\
\hline 11 & P15 & 65,26316 & 19,31579 & 0,722714 & 0,814452 & 0,835 & $\begin{array}{l}\text { Lolos Uji Validitas } \\
\& \text { Reliabilitas }\end{array}$ \\
\hline 12 & P16 & 65,36842 & 20,57895 & 0,515153 & 0,825992 & 0,835 & $\begin{array}{l}\text { Lolos Uji Validitas } \\
\text { \& Reliabilitas }\end{array}$ \\
\hline 13 & P17 & 65,36842 & 20,91228 & 0,245263 & 0,835496 & 0,835 & $\begin{array}{l}\text { Lolos Uji Validitas } \\
\text { \& Reliabilitas }\end{array}$ \\
\hline 14 & P18 & 65,31579 & 19,89474 & 0,448397 & 0,825867 & 0,835 & $\begin{array}{l}\text { Lolos Uji Validitas } \\
\text { \& Reliabilitas }\end{array}$ \\
\hline 15 & P20 & 65,36842 & 19,46784 & 0,610945 & 0,818344 & 0,835 & $\begin{array}{l}\text { Lolos Uji Validitas } \\
\& \text { Reliabilitas }\end{array}$ \\
\hline 16 & P21 & 65,31579 & 20,45029 & 0,319771 & 0,832409 & 0,835 & $\begin{array}{l}\text { Lolos Uji Validitas } \\
\& \text { Reliabilitas }\end{array}$ \\
\hline 17 & P21 & 65,31579 & 20,45029 & 0,319771 & 0,832409 & 0,835 & $\begin{array}{l}\text { Lolos Uji Validitas } \\
\& \text { Reliabilitas }\end{array}$ \\
\hline
\end{tabular}

Perolehan angka cronbach's alpha if item deleted pada ke 17 variabel yang lolos uji, berada pada nilai cronbach's alpha sebesar 0.835 Hal tersebut bermakna bahwa dari 22 item pernyataan original dari konsep parasuraman yang digunakan dalam penelitian ini, diperoleh hasil 17 item pernyataan lolos uji validitas dan reliabilitas. Dengan kata lain terdapat 5 item pernyataan yang tidak lolos dari uji ini dan di eleminir atau dikeluarkan dari instrument penelitian ini. Eliminasi tersebut dilakukan berdasarkan hasil uji internal consistency cronbach's alpha guna menjamin pengukuran yang tepat dan konsisten. Bila nilai cronbach's alpha if item deleted lebih kecil dari nilai cronbach's alpha keseluruhan, maka diputuskan bahwa variable tersebut dinyatakan valid dan reliable serta akan dikeluarkan. Dengan demikian instrument yang reliable untuk digunakan dalam mengukur kualitas layanan di kantor desa termodifikasi menjadi tujuh belas (17) item, meliputi : dimensi Tangible (3 item). dimensi Reliability (5 item), dimensi Responsiveness (2 item), dimensi Assurance (4 item), dan dimensi Emphaty (3 item).

\section{Uji Validitas Instrumen}

Uji validitas untuk instumen Servqual pengukur kualitas layanan di kantor desa tunjungtirto terdiri dari 5 Dimensi kualitas layanan dengan Total item yang digunakan adalah sebanyak 22 item Jumlah sampel uji adalah sebanyak tiga puluh (30) responden yang diambil secara acak dari kerangka sampel yang sudah ditetapkan sebelumnya. Hasil uji tersebut disajikan pada tabel berikut :

Tabel 2 Hasil uji validitas instrument

\begin{tabular}{|l|l|c|}
\hline \multicolumn{2}{|c|}{ KMO and Bartlett's Test } \\
\hline $\begin{array}{l}\text { Kaiser-Meyer-Olkin Measure of Sampling } \\
\text { Adequacy. }\end{array}$ & .687 \\
\hline $\begin{array}{l}\text { Bartlett's Test of } \\
\text { Sphericity }\end{array}$ & Approx. Chi-Square & 34.803 \\
\cline { 2 - 3 } & df & 10 \\
\hline
\end{tabular}




\begin{tabular}{|c|c|c|}
\hline \multicolumn{3}{|c|}{ KMO and Bartlett's Test } \\
\hline \multicolumn{2}{|c|}{$\begin{array}{l}\text { Kaiser-Meyer-Olkin Measure of Sampling } \\
\text { Adequacy. }\end{array}$} & .687 \\
\hline \multirow{3}{*}{$\begin{array}{l}\text { Bartlett's Test of } \\
\text { Sphericity }\end{array}$} & Approx. Chi-Square & 34.803 \\
\hline & $\mathrm{df}$ & 10 \\
\hline & Sig. & .000 \\
\hline
\end{tabular}

Nilai Kaiser-Meyer-Olkin MSA (KMO-MSA) sebesar 0,687 menunjukkan bahwa hasil Valid $(0.687>0.60)$. Dengan demikian, syarat pertama telah terpenuhi dan dapat dilakukan pengujian selanjutnya. Kedua, nilai Bartlett's Test of Sphericity sebesar 34.803 pada signifikansi 0,000. Oleh karenanya dapat dinyatakan bahwa ke 22 variable dimensi kualitas layanan sudah valid (sahih).

\section{Hasil Pengukuran Servqual Gap}

Hasil pengukuran gap kualitas layanan diperoleh skor postif,, dengan skor berada pada range s/d 0.4. Hal tersebut bermakna bahwa kualitas layanan yang diterima warga cenderung ke sangat berkualitas. (delight quality). Secara lengkap hasil dari pengukuran servqual gap disajikan pada tabel berikut:

Tabel 3 Hasil Servqual Gap

\begin{tabular}{|l|c|c|c|}
\hline & Mean & Mean & SQ \\
\cline { 2 - 4 } Item variable & Persepsi & $\begin{array}{c}\text { Ekspe } \\
\text { ktasi }\end{array}$ & Gap \\
\hline Secara phisik kantor terlihat bersih dan menarik untuk dilihat & 4.1 & 3.7 & 0.4 \\
\hline Karyawan kantor selalu nampak ada /hadir disekitar kantor & 4.0 & 3.6 & 0.4 \\
\hline Form dokumen untuk pelayanan terlihat bagus. & 3.7 & 3.5 & 0.2 \\
\hline $\begin{array}{l}\text { Dalam memberikan pelayanani Pada anda Karyawan selalu menepati } \\
\text { janji }\end{array}$ & 3.5 & 3.4 & 0.2 \\
\hline $\begin{array}{l}\text { Karyawan menunjukan kesungguhan dalam memberikan pelayanan pada } \\
\text { anda. }\end{array}$ & 3.9 & 3.6 & 0.3 \\
\hline Karyawan segera melayani anda. & 3.9 & 3.6 & 0.3 \\
\hline Karyawan melayani sesuai urutan antrian anda & 4.1 & 3.7 & 0.4 \\
\hline $\begin{array}{l}\text { Karyawan mencatat dan memeriksa secara akurat kebutuhan dokumen } \\
\text { anda. }\end{array}$ & 4.0 & 3.6 & 0.3 \\
\hline Karyawan Tanggap dalam melayani anda & 3.8 & 3.6 & 0.2 \\
\hline Karyawan Tidak Nampak sibuk dalam melayani anda. & 3.5 & 3.4 & 0.1 \\
\hline Karyawan kantor desa dapat dipercaya & 3.6 & 3.5 & 0.1 \\
\hline Anda merasa nyaman dalam berinteraksi dengan karyawan & 3.9 & 3.6 & 0.3 \\
\hline Karyawan memberikan perhatian pada kebutuhan anda. & 3.8 & 3.6 & 0.2 \\
\hline $\begin{array}{l}\text { Karyawan memahami bidang tugasnya sehingga mampu menjawab } \\
\text { pertanyaan anda. }\end{array}$ & 3.7 & 3.5 & 0.2 \\
\hline
\end{tabular}


Jurnal Teknologi dan Manajemen Industri, Vol. 4 No. 1, Februari 2018

Pascasarjana Institut Teknologi Nasional Malang

\begin{tabular}{|l|l|l|c|}
\hline Karyawan kantor desa memberikan perhatian pada anda & 3.8 & 3.6 & 0.2 \\
\hline Kebutuhan layanan anda sangat diperhatikan oleh karyawan. & 3.8 & 3.5 & 0.3 \\
\hline Anda membutuhkan perhatian dari karyawan kantor desa. & 4.0 & 3.6 & 0.4 \\
\hline
\end{tabular}

Dari hasil tersebut diatas secara managerial dapat dinyatakan bahwa (1) kondisi phisik kantor desa terlihat bersih dan menarik untuk dilihat, (2) Karyawan kantor selalu nampak ada /hadir disekitar kantor, (3) Karyawan mencatat dan memeriksa secara akurat kebutuhan dokumen warga, (4) warga membutuhkan perhatian dari karyawan kantor desa dan (5) Karyawan melayani sesuai urutan antrian warga. Kelima hal tersebut merupakan factor penentu kualitas layanan di kantor desa ini. Dengan demikian dapat dinyatakan bahwa kantor desa telah menyampaikan kualitas layanan yang prima kepada warga desa dengan baik.

Hal lain yang dapat ditingkatkan lagi agar performa pelayanan kantor desa menjadi berkualitas adalah : (1) Karyawan menunjukan kesungguhan dalam memberikan pelayanan pada warga, (2) Karyawan yang segera melayani warga, dan (3) Warga yang merasa nyaman dalam berinteraksi dengan karyawan.

\section{Kesimpulan}

Pengujian validitas \& reliabilitas Instrumen Servqual yang digunakan untuk mengevaluasi kualitas layanan kantor desa tunjung tirto sebagai penyelenggara pemerintahan di desa, diperoleh hasil dari ke duapuluh dua (22) item Parasuraman tereduksi menjadi tujuh belas (17) item yang tepat digunakan sebagai pengukur kualitas layanan pemerintah desa.

Hasil Servqual gap menunjukan bahwa secara umum persepsi warga lebih tinggi dibandingkan ekspektasinya. Hal tersebut bermakna bahwa warga menerima layanan pada skor berkualitas.

\section{Referensi}

1. Kepmenpan No. 63/KEP/M.PAN/7/2003

2. Parasuraman et al. 1985, 1988, A Multiple item Scale for measuring Customer Perception of service Quality. Journal of retailing 64 (1), 12-40 